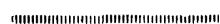

論文

UDC $669.158: 669.24: 532.72: 669.14 .018 .8$

\title{
電析ニッケルー炭素鋼拡散対における拡散層の状態*
}

\author{
岡田健**. 松 本 誠 臣***
}

\section{Diffusion Layers of Electroplated Nickel on Plane Carbon Steels}

Ken OKada and Shigeomi Matsumoto

Synopsis:

A study has been made of the diffusion behavior of electrodeposited nickel on various plain carbon steels. Influences of carbon contents in the various stcels used as substrate, heat treatment temperature and holding time on the structure, composition, hardness are of produced diffusion layer are described.

The results are summerized as follows;

1) The diffusion layer is formed even after heat treatment at a comparatively low temperature such as $600^{\circ} \mathrm{C}$.

2) The diffusion occurs by volume diffusion process in the temperature range between $600^{\circ} \mathrm{C}$ and $800^{\circ} \mathrm{C}$, while it occurs by grain boundary diffusion process in the temperature range between $900^{\circ} \mathrm{C}$ and $1000^{\circ} \mathrm{C}$

3) Some carbides are observed in the diffusion layer, but the kind and type of carbides were not determined by $\mathrm{X}$-ray diffraction in the all steels tested has a comparatively good resistance against nitric acid, and its hardness is as low as 170 in knoop handness.

\section{1. 緒言}

鉄錩材料表面に他の金属元素を浸透させる方法として 種々あげられ，それらの検討も多いが，てれらの川に工 業的に利用洒值が高いものとして若えられるニッケルを 浸透させることに関する検討は比較的少ない1)2. 最近 鉄鋼材料上に二ッケルめつきを施しその疲労強度につい ての検討3)など見られるが，これに熱好理を施し拡散浸 透させ表面の夕を高二ッケル鋼化した材料に関する報告 はほとんどないようである。筆者らは，良来より鉄鋼圭 面のステンレス鋼化を目的として個々の検討を行なつて いるが4)5)6)， $\mathrm{Fe}-\mathrm{Ni}$ 炭においても，電析を用いること により $\mathrm{Fe}, \mathrm{Ni}$ 固相間において比較的低温:こても顕微鏡

Table 1. Nickel plating condition.

\begin{tabular}{lr|lc}
\hline Nickel bath composition & \multicolumn{2}{|c}{ Condition } \\
\hline $\mathrm{NiSO}_{4} \cdot 6 \mathrm{H}_{2} \mathrm{O}$ & $300 \mathrm{~g} / l$ & Temperature & $50^{\circ} \mathrm{C}$ \\
$\mathrm{NiCl}_{2} \cdot 6 \mathrm{H}_{2} \mathrm{O}$ & $45 \mathrm{~g} / l$ & Current density $4.5 \mathrm{~A} / \mathrm{dm}^{2}$ \\
$\mathrm{H}_{3} \mathrm{BO}_{3}$ & $30 \mathrm{~g} / l$ & Duration & $10 \mathrm{hr}$ \\
\hline
\end{tabular}

的に可視できるていどに拡散合金層が生成されることが みとめられた5)。 また， $\mathrm{Fe}-\mathrm{Ni}$ 間においては，低温，高 温とでその拡散のし方が異なつており, 低温時には粒内,

Table 2. Compostion of Steels (\%).

\begin{tabular}{c|c|c|c|c|c}
\hline & C & Si & Mn & S & P \\
\cline { 1 - 6 } S 15C & 0.13 & 0.16 & 0.25 & $0.035<$ & $0.060<$ \\
\hline S 20C & 0.17 & 0.16 & 0.30 & $0.035<$ & $0.030<$ \\
\hline S 22C & 0.22 & 0.20 & 0.32 & $0.035<$ & $0.030<$ \\
\hline S 25C & 0.25 & 0.23 & 0.37 & $0.035<$ & $0.030<$ \\
\hline S 30C & 0.33 & 0.24 & 0.65 & $0.035<$ & $0.030<$ \\
\hline S 35C & 0.36 & 0.24 & 0.66 & $0.035<$ & $0.030<$ \\
\hline S 45C & 0.46 & 0.25 & 0.68 & $0.035<$ & $0.030<$ \\
\hline S 48C & 0.56 & 0.25 & 0.65 & $0.035<$ & $0.030<$ \\
\hline S 55C & 0.55 & 0.27 & 0.67 & $0.035<$ & $0.030<$ \\
\hline SK 3 & 1.03 & 0.21 & 0.37 & $0.030<$ & $0.030<$ \\
\hline
\end{tabular}

* 炤和 49 年 4 月本会蓝演大会にて発表 昭和 50 年 9 月 2 日受付 (Received Sep. 2, 1975)

** 武秥工業大学大学院 (Graduate School, Musashi Institute of Technology, 1-28-1 Tamatumi Setagaya-ku Tokyo 158)

*** 武蔵工業大学 工博 (Musashi Institute of Technology) 


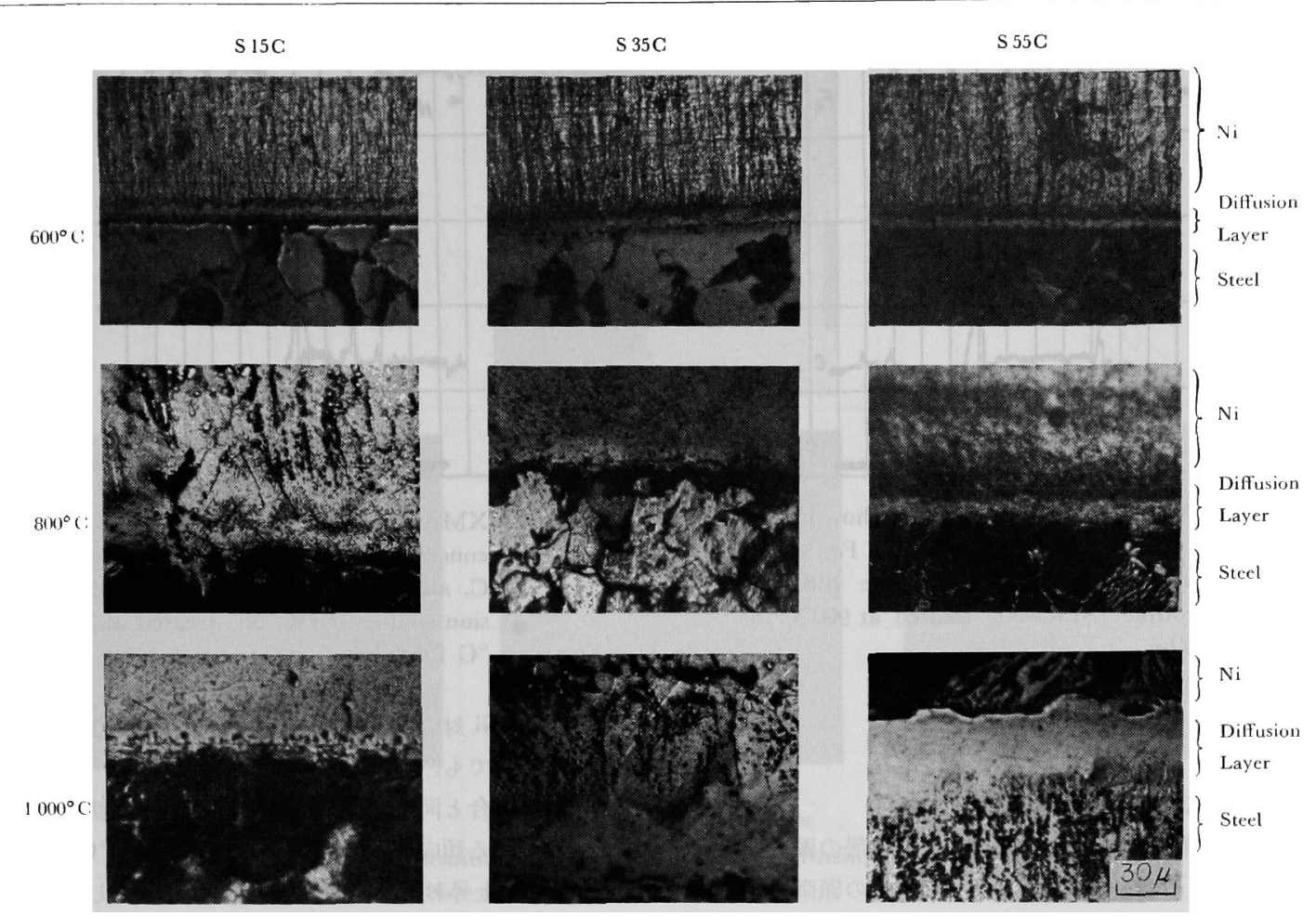

Photo. 1. Microphotographs of diffusion zone carbon steel-Ni couple ; diffused at $600^{\circ} \mathrm{C}, 800^{\circ} \mathrm{C}, 1000^{\circ} \mathrm{C}$ for 5 hrs.

高温時には粒界拢散現象を示すことがわかつた。そこで 本報告は，各種炭素鋼心二ッケルめつきを施して比較的 低温度より広範囲にわたり熱処理を施して生じた合金層 の組成および組䋨などについて梌討したこょについて報 告する.

\section{2. 実 験 方 法}

\section{$2 \cdot 1$ 拡散対試料}

試料の作成は，Table 1 亿示した標準カット浴組成な らびに条件下にて，常法による前処理，すなわち，トリ クロールエチレン脱脂, アルカリ脱脂, 酸洗を行ない得 た洗浄面にニッケルを電析させて, 鋼ーニッケル拡散対 試料を作成した。尚，ニッケル電析層厚さは， $0.2 \mathrm{~mm}$ 以上とした。 また使用した鋼組成は Table 2 に示した。

\section{$2 \cdot 2$ 熱処理条件}

熱処理は, $\mathrm{BaCl}_{2}, \mathrm{NaCl}, \mathrm{KCl}$ の混合塩浴中にて, $600^{\circ} \mathrm{C}$ から $100^{\circ} \mathrm{C}$ 間隔で $1000^{\circ} \mathrm{C}$ まで, それぞれ, $3 \mathrm{hr}$, $5 \mathrm{hr}, 7 \mathrm{hr}$, 加熱保持後直ちに水冷を行なつた.

\section{$2 \cdot 3$ 拡散層厚さ, 組織, 組成検査}

昖散層断面を鏡面に仕上げたのち，鉄鋼側をナイタル
にて腐食, 洗浄㣪, 試料を乾燥させた後濃硝酸でニッケ ル部を腐食して顕微鏡組織を観察した。交た同試料面を XMAにより面分析, 組成分析, 線分析老行なつて合金 層の組成变化を測定，濃度の定量は， Fe，Ni はそれぞ れ電解鉄, 電解ニッケル上の強度比より, 炭素はダイヤ モンドに炭素をコーティングしたものを標準試料とした 強度比より行なつた．同時にその組成変化点より合金層 厚さをも測定しだ.な招同試料ニッケル電析層側表面 より順次エメリー紙により約 $10 \mu \mathrm{m}$ ずつ削り各面に対し

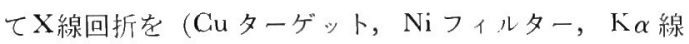
$40 \mathrm{kV}, 20 \mathrm{~mA}$ ) 行ない得られた回折線と, A. S. T. M 力 ードとを照合してその組織の定性的な判定をも試みた。

\section{4 かたさ測定}

鏡面仕上げを施した昖散対断面を, 拡散層の中央部と 考えられる個所を $0 \mu \mathrm{m}$ としてその近傍を含め約 $5 \mu \mathrm{m}$ 間隔にてかたさの測定（スープ㠪子，荷重 $10 \mathrm{~g}$ ）を行 なつた。

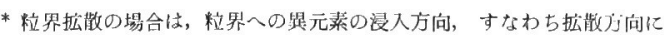

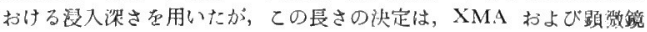
組維により平均的なる值を合金周厚さとした。
} 


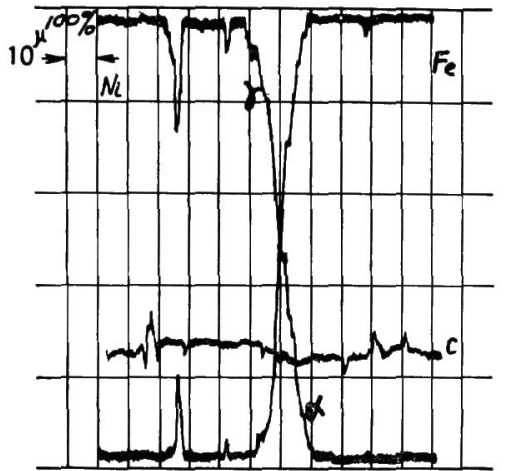

Fig. 1. XMA line scanning chart showing the concentration change of $\mathrm{Ni}, \mathrm{Fe}$, and $\mathrm{C}$ along the direction of the diffusion couple (S15C-Ni) treated at $900^{\circ} \mathrm{C}$ for $5 \mathrm{hr}$.

\section{3. 実 験 結 果}

\section{$3 \cdot 1$ 生成拡散層の顕微鏡組織}

各熱処理条件下において得られた搪散層の顕微鏡組絨 の代表例を Photo. 1 亿示した. これらの顕微鏡組織よ り次のことがわかる。术なわち，いずれの炭素含付壵の

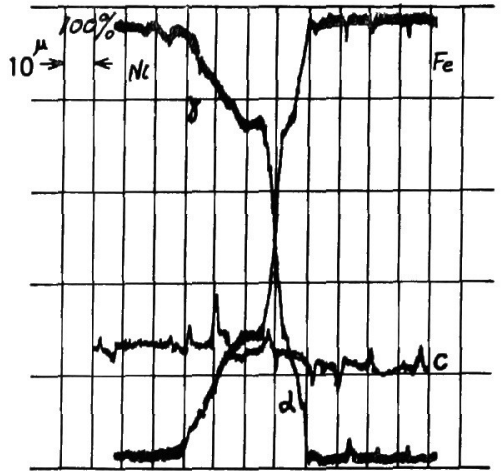

Fig. 2. XMA line scanning chart ${ }^{\top}$ showing concentration change of $\mathrm{Ni}, \mathrm{Fe}$, and $\mathrm{C}$, along the direction of the diffusion couple (S35C-Ni) treated at 900 ${ }^{\circ} \mathrm{C}$ for $5 \mathrm{hr}$.

舅合も， $\mathrm{Fe}-\mathrm{Ni}$ 刘の場合と同棑，600年のような比較的

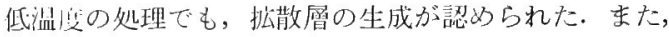
$\mathrm{Fe}-\mathrm{Ni}$ 対の場合と问様熱処理恃間の延長に伴い昖散層が 桨く生成される傾向が示された．さらに， $700^{\circ} \mathrm{C}, 800$ ${ }^{\circ} \mathrm{C}$ と温度の上昇抢よび，熱処理時間の延長にしたがっ

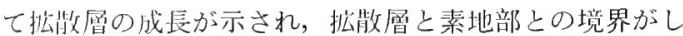

Composition Image

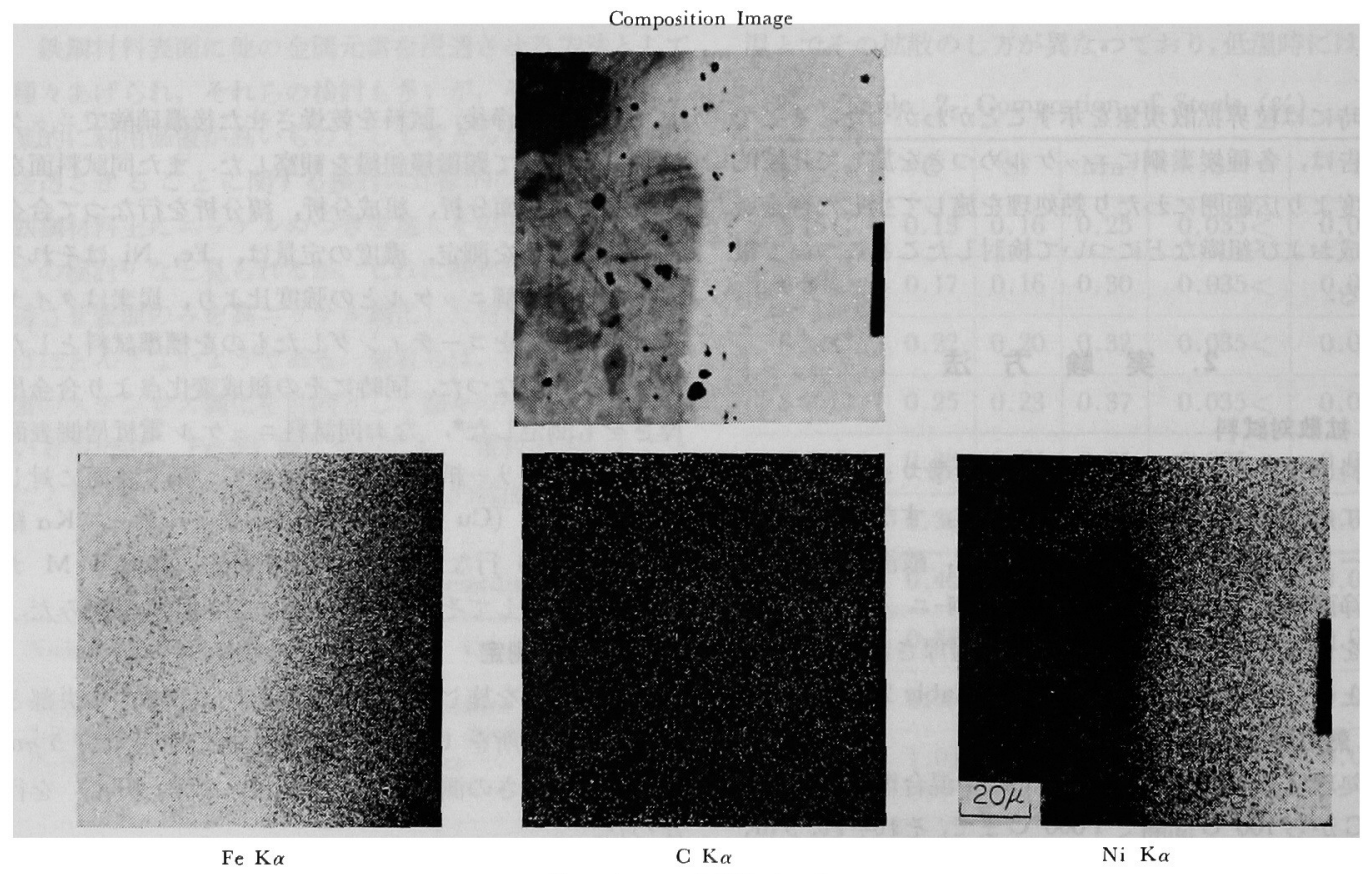

X-ray Images of Diffusion Zone

Photo. 2. XMA scanning images of $\mathrm{Ni}, \mathrm{Fe}, \mathrm{C}$, crossing the diffusion couple (S15C-Ni) treated at $900^{\circ} \mathrm{C}$ for $5 \mathrm{hr}$. 


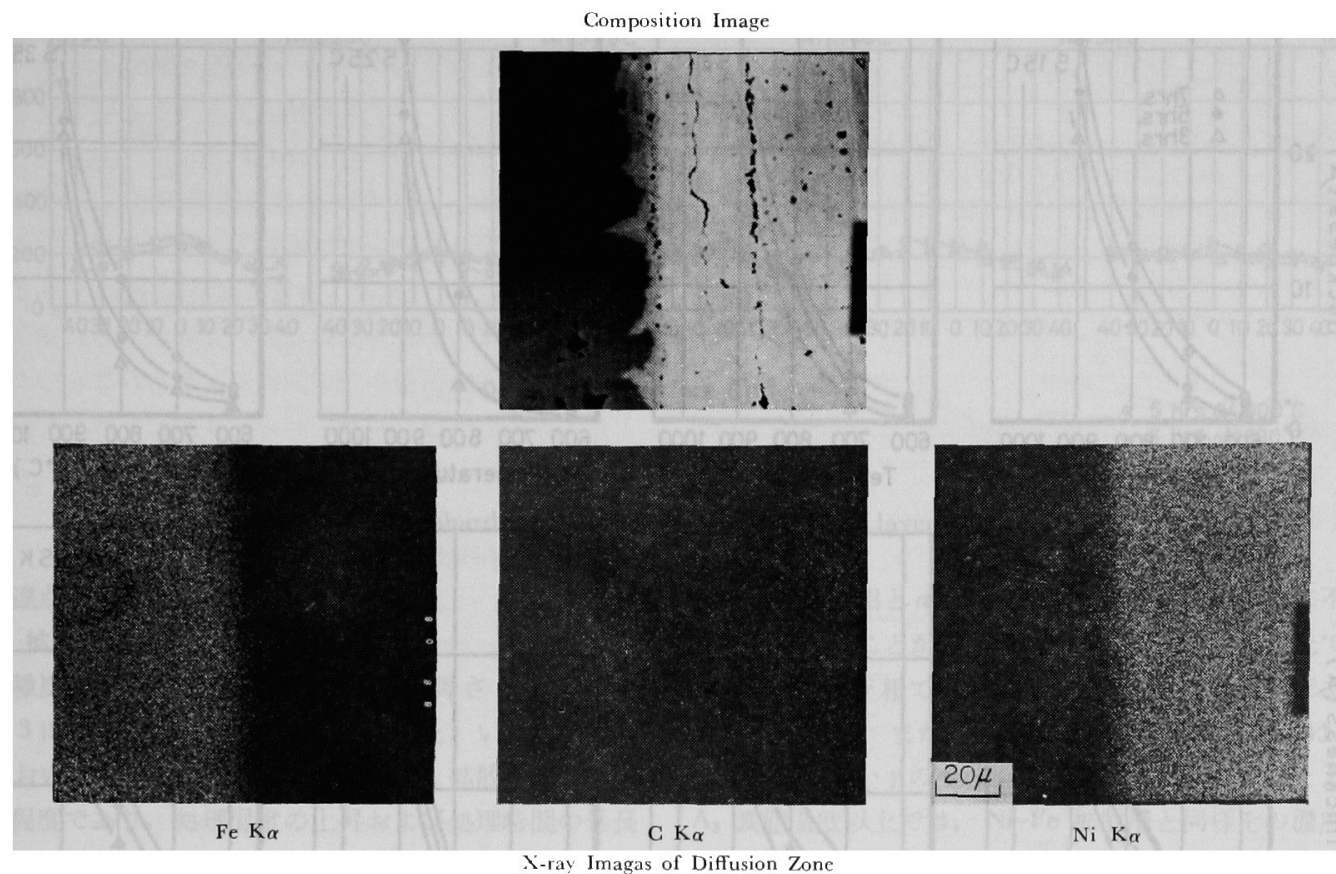

Photo, 3. XMA scanning images of $\mathrm{Ni}, \mathrm{Fe}, \mathrm{C}$, crossing the diffusion couple $\left(\mathrm{S} 35 \mathrm{C}-\mathrm{Ni}\right.$ ) treated at $900^{\circ} \mathrm{C}$ for $5 \mathrm{hr}$.

だいに不明膫になつていることが認められる。まだ， $800^{\circ} \mathrm{C}$ 以上の処理温度になると鉄鋼素地側粒界へわずわ ながらニッケルの浸透が灭られ，さらに，900 $\mathrm{C}$ 以上の 比較的高温においては，ニッケル側においてもその傾向 が示された。しかしながらニッケル側拡散層境界と鉄鋼 側昖散層境界を比較すると、ニッグ側の方が不明暸で あつた.

ここで炭素含有量の影響としては，顕微鏡的には顕著 でなく, $\mathrm{Fe}-\mathrm{Ni}$ 系の場合, 低温度処理と高温度処理とて, 前者が体拡散的であり後者が粒界拡散的であり，また熱 処理時間の増加にともなつて生成拡散層厚さの増加が見 られたが，本系にても認められた。な打，Cu ターゲッ トによるX線回折を試みたが，いずれの鋼種とも類似の 傾向を示した。すなわち，表面よりニッケルの回折線， ニッケルより多少低角側にシフトした $\alpha$ 固溶体との混合 した回折線，さらに $\alpha \mathrm{Fe}$ に近い回折線との混合した回 折線，および $\alpha \mathrm{Fe}$ の回折線となつて变化していること が認められたのみでその他化合物はこの結果よりは此い られなからた。

\section{2 拡散層の XMA 分析}

比較的低炭素含有量の例としてS15G-Ni 対，また， 比較的高炭素含有量の例として S $35 \mathrm{C}-\mathrm{Ni}$ 刘について $900^{\circ} \mathrm{C}$ にて $5 \mathrm{hr}$ 熱処理を施して得た拡散層およびその
近傍の，鉄，ニッケル，炭素の三元素の濃度分们を示す 線分析結情索 Fig. 1 および 2 に，また同断面での組成 像, 面分析像在 Photo. 2, 3 に示した. 線分析結果によ ると，いずれの昖散対とも顕微鏡組織において明らかに 組織の相違老示す椂な層は見られなかつたが，浱度曲線 は不連続になりわずかながらも定濃度部が示された。こ のような濃度分布は， $\mathrm{Fe}-\mathrm{Ni}$ 系において得られた同処理 条件での浱度分布ではニッケル側に抢いては比較的なだ らかなる浱度分布を示したのに対して異なる傾向が示さ れた。また炭素の濃度分布においては，いずれの炭素含 有量の場合も各熱処理温度とも, ニッケル電析層側の方 が，鋼素地側よりわずかに高い濃度を有する分布状態が 示されており，炭素とニッケルとの化合物と考兵られる 高濃度部は見られなかつた。 また， S15C-Ni 対と， $\mathrm{S} 35 \mathrm{C}-\mathrm{Ni}$ 対上の相違, 寸なわち, 炭素含有量の影絸々 しては, ニッケルと鉄との浱度分布の対称性に相違が見 られるようになつたことである。すなわち低浱度炭素含 有韭の場合の方が高濃度岑素含有量の場合よりも刘称性

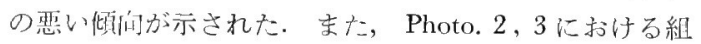
成像でも, S 15C-Ni 対の場合は写真中上部に粒界上思 わ机る個所が示され比較的深くニックルが公入している のに刘して，S $35 \mathrm{C}-\mathrm{Ni}$ 対の場合は䉼界と思われる個所 の間隔が比較的狭く，末たニッケルの洨入深さも浅いな 

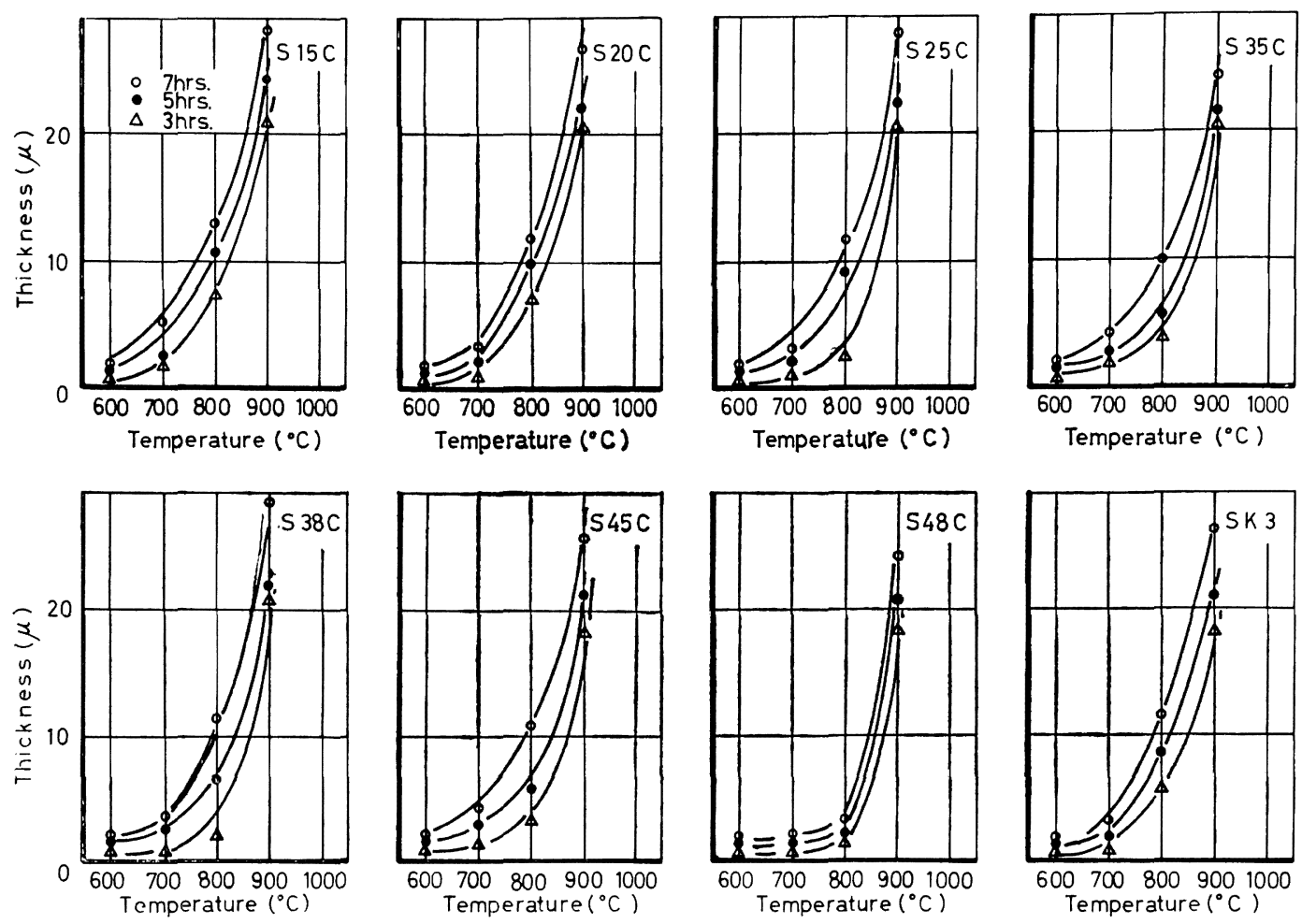

Fig. 3. Ni. alloying thickness for heat treatment temperature as function of steels.
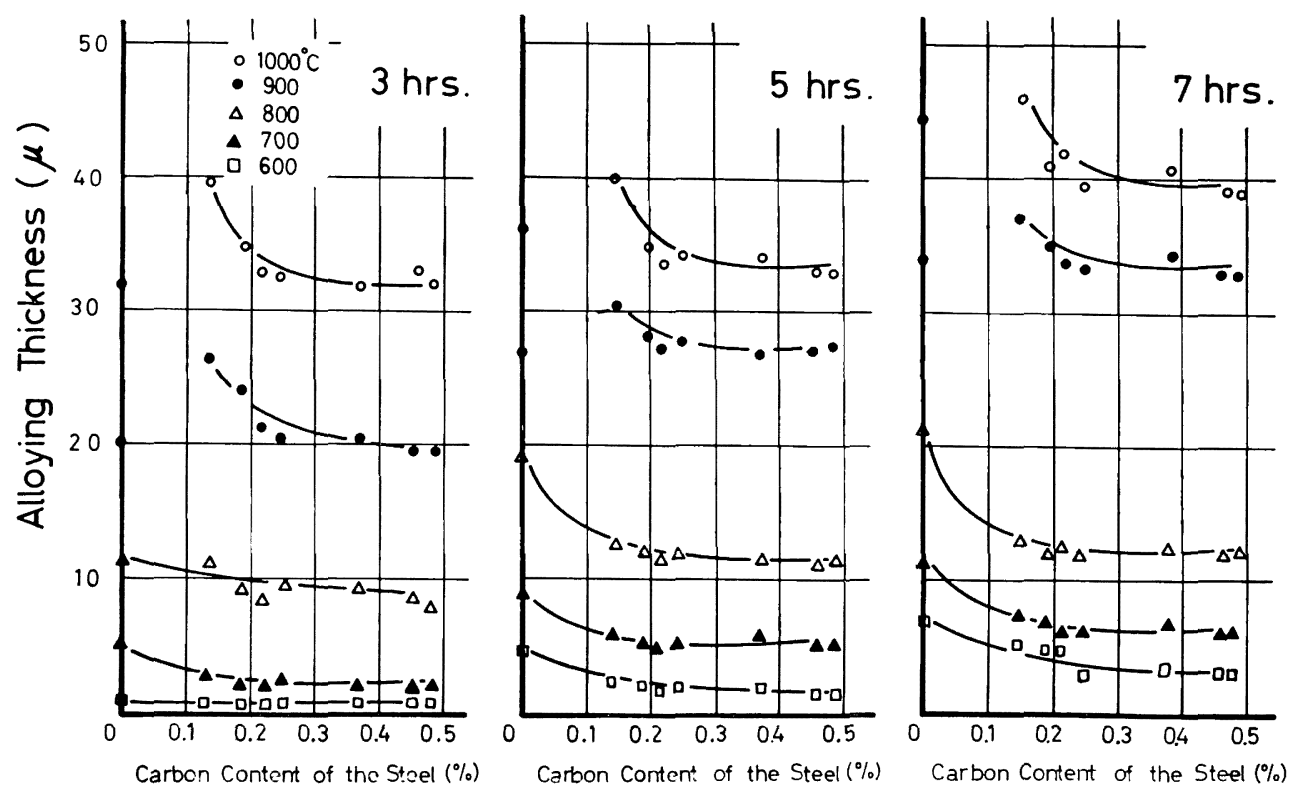

Fig. 4. Ni alloying thickness for annealing as function of the carbon conhent of the steels. 


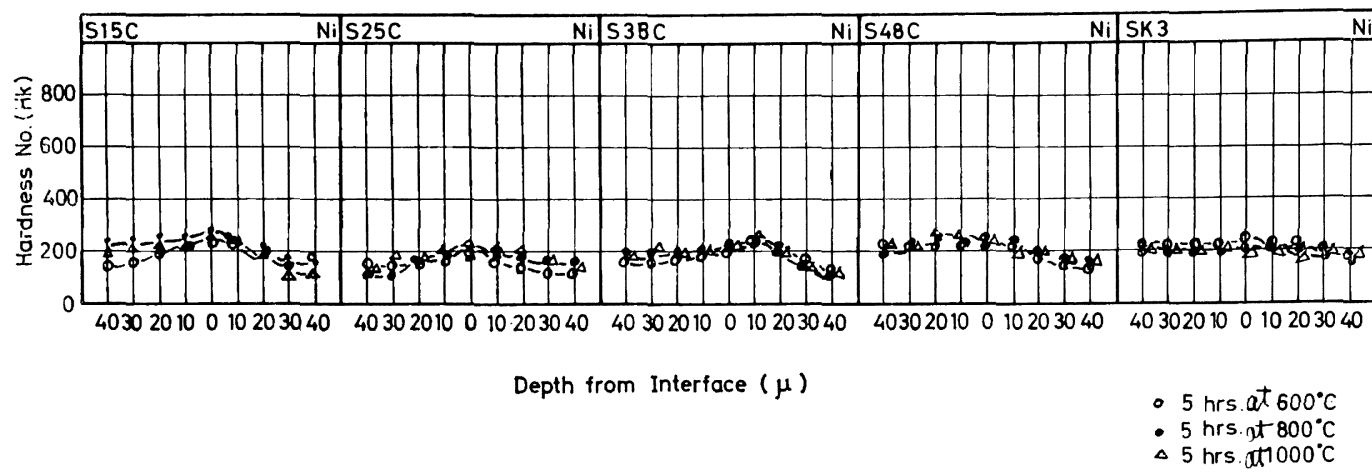

Fig. 5. Microhardness gradient across diffusion layer of steels.

\section{ど相違点が示された。}

\section{3 拡散層厚さ}

各種炭素鋼の 各熱処理条作と抁政層厚さとの関倸を Fig. 3 に示した.これらの結果によると，いずれの炭素 鋼においても $600^{\circ} \mathrm{C}, 3 \mathrm{hr}$ 処理では，拡散層厚さは数 $\mu \mathrm{m}$ 程度であり，処理温度の上昇および処理時間の延辰 に伴つて拡散層厚さは厚くなる，放物線則的な增加を示 した。また，それぞれの炭素含有量に対しては，いずれ も処理時間に対して同様の傾向が示された。 また，同一 熱処理温度下での処理時間に対して層の厚さの增加は 3 $\mathrm{hr}$ 処理の場合に得られた曲線と類似した傾向が示され た. Fig. 4 に各炭素含有量に対する拡散層厚さをプロ. トしたここれによると炭素含有量 $0.2 \%$ 以上において， 各熱処理時間，各熱処理温度下にてほぼ一定の昖散層厚 さを示した，また炭素含量が $0.15 \%$ 付近にて $900^{\circ} \mathrm{C}$ 以 上の処理温度において, 拡教層厚さの最大值が示される 傾向を得だ.

\section{4 拡散層およびその近傍のかたさ}

各処理温度下にて得られた拡散層および，その近傍の かたさ分布をFig. 5 に示した。この瓭によると，いずれ の炭素鋼においても，本拡散采では，その熱処理条件に よる大きな影響はなく，最小值 $170 \mathrm{Hk} ，$ 〜最大值 220 $\mathrm{Hk}$ 程度の狭範囲での变位が示された，すなわち，炭素 の影響と考允られる炭化物の存在を示すごときかたさの ピークは，示されなかつた。

\section{4. 考察}

\section{1 拡散層の組織, 組成}

$\mathrm{Fe}-\mathrm{Ni}$ 系の平衡状態図7) より $910^{\circ} \mathrm{C}$ 以下においては,

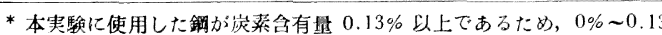

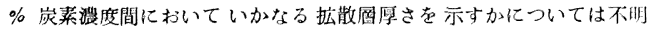
である、このことがらについては，上り緗く炭菜湍度を変化させて检 乱する必要がさると思われる。
拡散層山の $\gamma$ 相と $\alpha$ 相との觉界面をはさんで浱度に不連 続性を尘じることが莙えられる。一方 $910^{\circ} \mathrm{C}$ 以上では

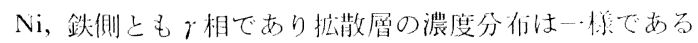
と考えられる。また，炭素の含有による影響で鋼は $\mathrm{A}_{3}$ 变態曲線に沿い子の生成温度は低下寸る。このことより $\mathrm{A}_{3}$ 变態温度以上では, $\mathrm{Ni}-\mathrm{Fe}$ 拡散層と同永云の搌焦分

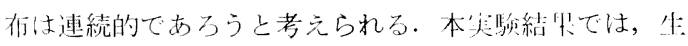
成した㧓散層の浱度分布はFig. 1，2 に示したごとくで あり, S $15 \mathrm{C}-\mathrm{Ni}$ 対の場合, 二ッケル浱度 $100 \%$ の部分 よりなだらかな濃度の減少を少し $\gamma$ 固溶体部がかなり広 く示され，始如の境界より鋼侧に $\gamma$ 相， $\alpha$ 㥵の界面が你 在し次いで, Fe-Ni の $\alpha$ 固溶体部が示されている。また 足濃度部は， $\mathrm{Fe}-\mathrm{Ni}$ 系より $\mathrm{Ni}$ 濃度の高い，たいたい $70 \sim 75 \% \mathrm{Ni}$ 浱度付近に数 $\mu \mathrm{m}$ が示された.

また S 35C-Ni 刘の場合は，やはり $\mathrm{Ni}$ 浱度 $100 \%$ の 電析層部より浱度が減少し数 $\mu \mathrm{m} \sigma \gamma$ 固溶体部が示さ れ次いで，比較的連続的に浱度が減少して銅部に到つて いる. 寸なわち，\$15C-Ni 対において見られた $\alpha$ 固涳 体部は示されなかつた。 また，Photo. 2，3にも示した ごとく䤱側にてS $15 \mathrm{C}-\mathrm{Ni}$ 対の場合, 粒界部の幅が比較 的広く，その浸入深さも深いのに刘して，S 35C-Ni 対 の場合幅も狭く浸入深さも浅い傾向が示された.すなわ ちこれも炭素公有量の違いによる影㖣ではないかと考え られる、そこで，このことがらと，濃没分布において示 された非対称性との関連を考えて，粒界部においての濃 度分布を調ベたところいずれの炭素含有呈の場合も，速 続的なる濃度変化が示された。さらに，本系において示 された扒政畨の生成は，低温度時においては体拡散的て あり，高温度時においては，たと光ば $800^{\circ} \mathrm{C}$ 以上の高温 では鋼粒界へのニッケルの浸入の㯪先する， $\mathrm{Fe}-\mathrm{Ni}$ 采時 に見られたと同様粒界拡教的な傾向が示されている。こ のニッケルの粒界への拡散については，オーステナイト 

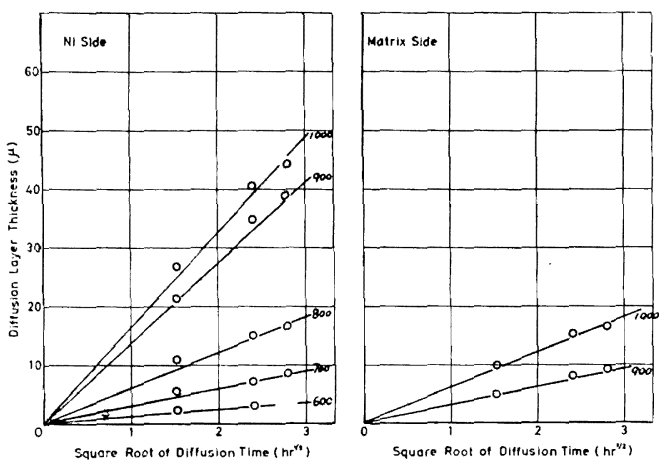

Fig. 6. Time dependence of width of diffusion layer at ezch temperatures. (S35C-Ni)

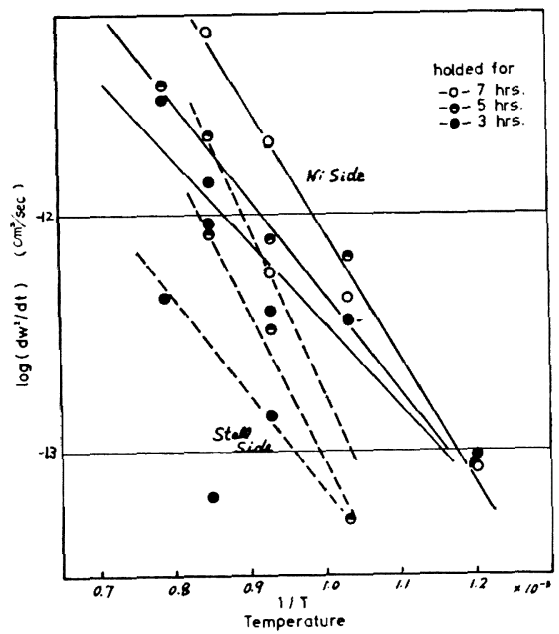

Fig. 7. Temperature dependence of $W^{2} / t$.

系合金鋼-ニッケル，クロムーニッケル，その他の金属と ニッケルの拡散対においてもニッケルの粒界拡散が優先 することが知られているごとく，ニッケルの特異な性質 と考えられる。このことは，オーステナイト樂合金鋼， すなわち，f.c.c. 鉄中あるいはフェライト，b.c.c. 鉄 けの二ッケルの自己拡散係数が2)8，鉄，ク口ムなどの てれと比してオーダーが 2〜3 桁小さいことと関係する ものと考えられ，このため体拡散は小さく精界抓散が傮 先专るものと考元られる。低温の場合体拡散涑度も粒界

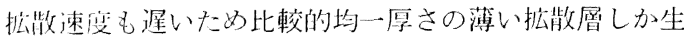
成されないが，高温になる程，特に電解鉄を分以低炭素 含有鋼においては粒界拡散が明睹に現われてきたものと 考允られる・ただ高炭素鋼において粒界拡散があまり顕 著に認められなかつたことおよひ，900`C 以上に招い ては，800 C 以下に比して拡散層厚さ，特化体拡散によ
る拡散層厚さが厚く生成されたことは，低温において低 炭素含有鋼における b. c. c. の $\alpha$ 固溶体がニッケルの淡 入により f. c. c. の $\gamma$ 固溶体に変態する変態速度も関係 しているのではないかと考えられる.

また炭素ーニッケル間における固溶範车の方が炭素一鉄 間におけるそれよりも大である7ここより推測できるよ うに，X 線回折においては特別なる化合物はみとめら れず，さらに，かたさ試験においても使用した䤱におけ る炭素含有量の影響が測定面内には見られなかつた。な ぞ炭䋕の昖散が速く䊀界, ニッケル側に昖散して鋼部に おいてはほぼ一定となつたことを示しているもの上茩え られる。

\section{2 拡散層(成長速度}

Fig. $3 ， 4$ に示した备処理条件下に括いて生成した搪

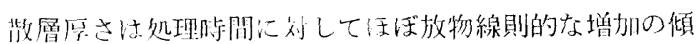
向がある。そこて时間の平方根を横軸に，層厚さを維軦 にとりプロットしたところ Fig.6のごレくなつた。これ より $800^{\circ} \mathrm{C}$ 以上の処理温度のものは直線よりずれを生 じる傾向がわかる，このことは，先にも述べた低温時に おいては体払散が主であり，高温度洔においては粒界拡 散が主となる扒散であつたことに刘応するものと考えら れる。亦た，Fig，7に扔いて示した各熱処理温度に刘す る㧙散層厚さへの影異, すなわら温度依存性に打いても $800^{\circ} \mathrm{C}$ 付近にて交わる 2 本の直線が得られ，その傾きは 一般に知られている ${ }^{19}$ 䊉内, 粒界据散の活性化エネルギ 一の相灌を示す比率と一致しているようであつた。

\section{5. 結言}

鋼一ニッケル采固相拡散について梭討を行なつた結果 次の結論が得られた。すなわち，

(1) $\mathrm{Fe}-\mathrm{Ni}$ 系に打いても示されたことがらである が，炭素を含も本采においても，600 $\mathrm{C}$ 程度の比較的低 温度にても顕微鏡的に抬散層の生成が認められた。

（2）拡散層の生成は，低温度域，高温度域にて異な る傾向が示された。すなわち，低温度域では，体应散的 であり，高温度域では粒界への浸透老主とする拡散現像 であることが判つたこの傾向は， $\mathrm{Fe}-\mathrm{Ni}$ 系においても 認められたことであるが，本系においてもとの傾向が認 められた。しししその拡散状態は $\mathrm{Fe}-\mathrm{Ni}$ 系とは異なつ て抢り，これは炭素が影響している様に思われる.

(3) 生成拡能層内での化合物の生成は, 炭素の含有 量に関係なく認められなかつた. そのためか, 生成拡散 層部のかたさは低く, 平均值 $200 \mathrm{HK}$ 程度であつた.

最後に, 本研究に対して種々有益な御意見を賜つた北 海道工業大学 吕戊辰教授に深謝の意を表します. 


\section{文献}

1) 細井, 近藤, 闬田：金属表面技術，18（1967）, p. 62

2 ) J. I. Goidstein: Trans. Met. Soc. AIME, 233 (1965), p.812

3 ) 砂田, 泉: 材料, 22 (1973), p. 1078

4) 岡田, 松本, 品：金属表面技術，25(1974), p. 256

5 ）岡田，松本，呂：金属表面技術，26（1975), p.
358

6 ）岡田，松本，号：金属表面技術，26 (1975)，p 363

7 ) Ma. Hansen: Constitution of Binary Akkoys, (1958), p.678, Mc Graw ttill Book Co.

9）ジョンウルフ編・永宮訳：材料科学入門「構造と 䱉力学」, (1973), p.83, 岩波書店

10) H. W. Paxton: Trans Met. Soc. AIME, 218 (1960), p.794 